\title{
IAMJ
}

INTERNATIONAL AYURVEDIC MEDICAL JOURNAL

\section{AYURVEDIC PERSPECTIVE OF PRIMARY DYSMENORRHOEA - REVIEW ARTICLE}

\author{
$\underline{\text { Asitha. }}^{1}$, N. Vijayakumar ${ }^{2}$
}

${ }^{1}$ MS (Ay) Specialist Consultant, Dr Divya's Ayurveda Gynecology and Fertility Speciality OP Clinic, Vanchiyoor, Trivandrum, Kerala, India

${ }^{2} \mathrm{MD}$ (Ay) Former professor and HOD, Dept of Prasutitantra-Streeroga, Govt. Ayurveda college, Trivandrum, Kerala, India

Corresponding Author: asithahari@gmail.com

\section{https://doi.org/10.46607/iamj03p5032021}

(Published online: March 2021)

Open Access

(C) International Ayurvedic Medical Journal, India 2021

Article Received: 17/02/2021 - Peer Reviewed: 09/03/2021 - Accepted for Publication: 11/03/2021

Check for updates

\begin{abstract}
The medical term for painful period is "dysmenorrhoea". Dysmenorrhoea among adolescents is of primary in nature that is without any pelvic pathology. Among Vimshati yonirogas described in Ayurveda classics Udavarta is mentioned as a condition with painful and difficult menstruation, so it can be correlated to primary dysmenorrhoea. In this condition the Rajas flow in reverse direction hence the term Udavartini. Women feel immediate relief following discharge of menstrual blood. Normal menstrual flow is the function of Apana vata therefore Apana vata dushti can be considered as the responsible factor for Udavarta. Because of the high prevalence of dysmenorrhoea in adolescents and extent of its potential daily interference it should be seriously taken into consideration. Ayurvedic classic textbook along with available modern literatures were referred to make a clear view regarding the concept of $U d a$ varta and its possible correlation with primary dysmenorrhoea.
\end{abstract}

Keywords: Primary dysmenorrhoea, Udavarta, dysmenorrhea 


\section{INTRODUCTION}

Menstruation is a natural phenomenon that occurs throughout the reproductive years of women and is a series of hormonal process a woman's body go through each month for a possible pregnancy. Some women get through their monthly periods easily with few or no concern and just cause little more than a minor inconvenience. During the menstrual period, most women experience some degree of pain and some sort of distress. As long as the Doshas function in their normal state and are not overshadowed by another Dosha, the menstrual cycle happens optimally. Pain is the most common problem women have with their period. The word dysmenorrhoea has a Greek origin, means difficult monthly flow and is now taken to mean painful menstruation. Primary dysmenorrhoea is characteristically when adolescents attain ovulatory cycles, usually within 6-12 months of menarche. Dysmenorrhoea is the most common cause of pelvic pain it results in activity restriction and thereby cause limitations on academic and sports activities, loneliness, depression, behavioural change like social withdrawal and restriction from daily activities.

Primary dysmenorrhoea is mostly confined to adolescents. Tension and anxiety during adolescence period decreases the pain threshold. Spasmodic dysmenorrhoea has certain connections with progesterone stimulus to the uterus. The pain is usually cured following pregnancy and vaginal delivery. The pain is related to dysrhythmic uterine contractions and uterine hypoxia. Behavioural and psychological factors, family history, abnormal anatomical and functional aspect of myometrium, uterine myometrial hyperactivity has been observed in cases with spasmodic dysmenorrhoea. Imbalance in the autonomic nervous control of uterine muscle and increased amount of prostaglandin causes hyperactivity of uterine muscles resulting in uterine ischemia and pain. An increase in vasopressin levels without an accompanying increase in oxytocin levels can cause uterine hyperactivity and dysrhythmic contractions results in ischemia and hypoxia which causes pain. Local myometrial ischemia caused by endothelins and PGF2 $\alpha$ aggravate uterine dysperistalsis and hyperactivity. Platelet aggravating factor and leukotrienes contribute to the uterine hypercontractility seen in primary dysmenorrhoea. The pain starts a few hours before or just with the onset of menstruation. Severe pain lasts for few hours and may extend to 24 hours, but seldom persist beyond 48 hours. The pain is spasmodic in nature and confined to lower abdomen; may radiate to the back and medial aspect of thighs. Systemic discomforts like nausea, vomiting, fatigue, diarrhoea and headache, tachycardia may occur. Vasomotor changes cause pallor, cold sweats and occasional fainting. In severe cases syncope and collapse may be associated. ${ }^{1}$

Udavarta is one among the twenty Yonirogas described in Ayurvedic classics. Painful menstruation and relief of pain after the establishment of proper menstrual flow are the characteristic feature of Udavarta. It can be considered as the most appropriate correlation for primary dysmenorrhoea described in modern textbooks.

\section{Udavarta}

"Udavarta Ithi Urdhwam Netham "2 - Udavarta word refers to upward movement."Vikarena Rajasa Urdhagamanat Udavarta Ettyuchate" - Urdhwa Gamana of Rajas is Udavartini

\section{Different Concepts of Udavarta}

Acharya Charaka mentioned that due to movement of flatus etc. natural urges in reverse direction, the aggravated Vayu moving in reverse direction fills the Yoni. Thus, Yoni seized with pain initially throws or pushes the Raja upwards, then discharges with great difficulty. ${ }^{3}$ "Artave Sa Vimukte Tu Tat Kshanam Labhate Sukham" which means after the proper establishment of menstrual flow the pain relieves. The duration of menstrual pain in spasmodic dysmenorrhoea is limited to 24-48 hours. Charaka also says that in this condition the Raja moves upwards or in reverse direction hence, it is termed as Udavartini. Both Vagbhatas have followed Charaka mentioned that due to Vegadharana the aggravated Apana Vata moving in reverse direction and the Yoni is seized with pain. Release of Badha Rajo Rakta occurs and it can be correlated to discharge of clotted menstrual blood when there is reduced fibrinolytic activity. Susruta in Uttara Stana giving a very short description about the disease, says that besides 
painful frothy menstruation there are other pains of Vata (Anila Vedana). Here Anila Vedana can be taken as low back ache, pain radiating to legs, headache, general malaise etc. Samanthad Vritam Varthulam Yatra Vayuna mentioned in Madhava Nidana represents the overall movement of Vayu in the uterus. It can be related to irregular myometrial contractions, is considered as the one of the contributing factors for primary dysmenorrhoea. Yogaratnakara points out the association of Kapha in the menstrual discharge in Udavarta is given as $\mathrm{Sa} \mathrm{Tu}$ Yoni Kaphenaivartavam Cha Vimunchati. If it is considered as associated with mucous membrane or endometrial fragments, it is comparable to membranous type of dysmenorrhoea.

Nidana (aetiology)

\section{Vishesha nidana of Udavarta}

Vegadharana is the Vishesha nidana responsible for Udavarta. $^{5}$ Vegadharana includes Adhovatadi Vegadharana. Expulsion of Adhovata, Sukra, Mala, Mutra, Artava is the function of Apana Vata. According to Vagbhata Samana Vata also carries Dosha, Artava, and Ambu. So, any Nidana which vitiate these results in Udavarta Yonivyapat.

Samprapti (Pathogenesis)

By the above mentioned Nidana Seva aggravation of Vata and derangement of Kapha occurs. The aggravated Vata especially Apana Vata when faces Marga avarodha the normal Gati of Vata is affected and results in Vimarga gamana. In addition to this unusual contraction of cervix and body of uterus are associated. Along with the Vimaragamana of Vata there occurs Vimargagamana of Rajas. Due to this manifestation of severe pain and difficult discharge of frothy Rajas took place. All these events contributing to difficulty in expulsion of Rajas or painful expulsion of Rajas.

Here there is Srotodushti and Srotas involved is $\mathrm{Ar}$ tavavaha Srotas. Two types of Srotodushti is there Vimargagamana, that is the Artava moving in the reverse direction and the Sanga as the menstrual blood is directed in the reverse way, it stays longer in the Yoni and discharged with difficulty.

\section{Samprapti Ghatakas}

Dosha - Vata, Kapha as Anubhanda dosha (Vata Vyana, Apana,

Pitta - Ranjaka, Pachaka

Dooshya - Rasa, Rakta,

Srotas - Artavavaha Srotas

Srotodushti prakara - Sanga, Vimargagamana

Roga marga - Abhyantara

Prabhava sthana - Pakwasaya

Sthana samsraya - Garbhasaya

Vyakta sthana - Garbhasaya

\section{Purvarupa}

Few hours or a day prior to menstruation slight low back ache or lower abdominal pain manifest as Purvarupa.

\section{Rupa}

\begin{tabular}{|c|c|}
\hline Rajakrichrata 6 & Difficult discharge of menstrual blood \\
\hline Artave Sa Vimukte Tu Tatkshanam Labhate Sukham ${ }^{7}-$ & Immediate relief following discharge \\
\hline Phenila Artavam ${ }^{8}$ & Frothy menstrual blood \\
\hline Anila Vedana ${ }^{9}$ & Other pains of Vata like malaise, body ache \\
\hline Kapha Samsrishta Artava ${ }^{10}$ & discharge of menstrual blood with Kapha \\
\hline Badham Phenilam Phenayuktam Rajo Raktam ${ }^{11}$ & Discharge of clots along with menstrual blood \\
\hline $\begin{array}{l}\text { Samanthat Vritam Varthulam Yatra Vayuna Sa } \\
\text { Thadha }^{12}\end{array}$ & irregular uterine contractions due to all around movement of $\mathrm{Vayu}$ \\
\hline Kaphenaivam Artavam Cha Munjati & difficult discharge of menstrual blood with Kapha. \\
\hline
\end{tabular}

Upasaya (Relieving factors)

- Vatanulomana Aharas

- Vatanulomana Viharas

- Bahya Ushna Prayoga on lower abdomen

\section{Anupasaya (Aggravating factors)}

- Vata Prakopa Aharas

- Vata Prakopa Viharas 


\section{Differential Diagnosis}

Among Yonirogas mentioned by different Acharyas, pain associated conditions are seen in the following Yonirogas.

1. Vatiki, 2. Vataja Artavadushti, 3. Vatika asrigdara, 4. Paripluta, 5. Sannipatiki yoni vyapat, 6. Suchimukhi, 7. Antarmukhi, 8. Vipluta.

Kastartava is also found in Vatiki, Vataja artavadushti, Sannipatiki, Antarmukhi, Suchimukhi, Vipluta etc.

\section{Upadrava}

As specific Upadravas of Udavarta are not mentioned in classics, those mentioned for Yoni vyapath can be considered. Thus Pradara, Gulma, Arshas, Vandhyatwa etc. can be considered as Upadravas.

\section{Sadhyasadhyata}

In classics Udavarta is described as a Vatika yoni vyapat, since it is Eka Doshaja, Udavarta can be considered as a Sadhyaroga.

\section{Chikitsa}

As Vata Vaigunya is the root cause of Udavarta correction of vitiated Vata and removal of the cause are the treatment principle to be adopted in Udavarta chikitsa.

\section{Specific Treatment}

Snehana with Trivrita sneha (mixture of Grita, Taila, Vasa), Swedana, use of Gramya, Anupa, Audaka mamsa rasa, Vasti and Pana of Ksheera prepared with Dasamula, Anuvasana vasti and Uttara vasti with Trivrita sneha ${ }^{13}$. In Astanga samgraha it is mentioned that Vatika yonirogas including Udavarta all Vatahara upakrama should be done. Yoni pichu with Taila made up of Kushta, Tagara, Devadaru, Vartakini and Saindhava ${ }^{14}$ Medicated oil prepared with decoction of Rasna, Malati, Chinnaruha, Madhuka, Bala, Vyaghri, Devadaru, roots of Chitraka, Yuthika each one Karsa, one Prastha of oil, cows urine and two parts of cowsmilk. Diaper soaked in this oil and put into vagina relieves the pains caused by Anila. ${ }^{15}$

\section{Samanya Chikitsa}

General principles of treatment

- Snehana with Sukumara Ghrita

- Swedana

- Virechana - It is the most appropriate Shodhana as Apanavata Vaigunya is the root cause.
- Vasti can be administered using Saptasaram kashaya, Sukumara Ghrita Satapushpakalka combination.

- Uttara vasti- It helps in removing the blockage of channels, Vata Samana and Brahmana to Garbhasaya. Sukumaram Ghritam, Phalasarpis are some of the Yogas used for administration of Uttara vasti

- Vata Samana Pralepa, Parisheka, Avagaha, Pichu etc. can be administered according to the condition of Doshas.

- Snigdha, Ushna, Amla, Lavana Dravyas should be used for the relief of menstrual disorders from Vata.

- For Avrita Apana Vayu, treatment should be Agnideepaka, Vatanulomana, and Pakvasaya Shudhikara.

\section{Shamana yogas}

Saptasaram Kasayam, Sukumaram Kasayam, Dhanwantaram Kasayam, Maharasnadi Kasayam, Rasna Swadamstradi Kseerapakam, Pachottikoovaladi Kasayam, Hinguvachadi Churnam, Pushyanugam Churnam, Sukumara Ghritam, Phala Sarpis, Kumaryasvam, Asokarishtam, Rajapravartini Vati, Dhanwantaram Gulika

\section{External medicines}

Saindhavadi Taila Pichu, Guduchyadi Taila Pichu, Dhatakyadi Taila Pichu, Palasha Niruha Vasti, Shatavaryadi Anuvasana Vasti, Guduchyadi Rasayanika Vasti, Baladi Yamaka Anuvasana Vasti, Shatavaryadi Rasayana Vasti, Mushaka Taila Pichu

\section{Yogasanas}

Asanas found to be effective in dysmenorrhoea are Halasana, Sarvangasana, Bhujangasana, Ardhamatsyendrasana and Pranayama like Nadishodana and relaxation technique like Shavasana. It increases the circulation of blood and flow of vital energy to reproductive organs and establishes balance among hormones regulating menstruation. ${ }^{16}$

\section{Pathya-Apathya}

General Pathya- Apathyas mentioned for Yoni rogas can be consider for Udavarta yonivyapat also. 


\section{DISCUSSION}

Samanya nidana of Yonirogas like Mithya achara Pradushtartava, Beeja Dosha and Daiva can also be included as the cause of Udavarta. Mithya aharas like Alpa Ruksha Sushka Ahara, Athyasana, Vvshama Asana, Virudha Ahara, Vatala Aharas and Akala bhojana causes vitiation of Vata. There is significant relation between dysmenorrhoea and nutrition. Dysmenorrhoea is considerably higher in girls who are consistently eating fast food. Junk foods lack macronutrients and are rich in saturated fatty acids. These acids affect the metabolism of progesterone in menstrual cycle, which might be responsible for triggering dysmenorrhoea. In short, the Ahara consumed must be Hita for maintaining the Doshas in equilibrium and thereby the Aroga avastha of the reproductive system is assured.

Viharas include different types of lifestyle (dos and don'ts) as suggested in Ayurveda. Mithya vihara include Vegadharana, Ativyavaya, and coitus in improper posture or with Apadravyas. Abstinence from following proper Ritumati Charya and indulging in strenuous activities especially during the menstrual period may predispose dysmenorrhoea. Sedentary lifestyle, and suppression of natural urges especially in students and working women are commonly seen Mithya viharas. Vegadharana causes Vata vitiation and the vitiated Vata causes the vitiation of other two Doshas also. Among these causes sedentary lifestyle is Abhishyandi in nature and cause Kapha Dushti.

Ratrijagarana (night awakening) one Mithya vihara followed by students. It leads to Vata prakopa and Agni Dushti. Wakefulness in night causes disturbance in the activity of digestive enzymes result in indigestion. Day time sleep is Abhishyadi and causes Tridosha dushti according to Susruta and Kapha dushti and physiological reduction of Pitta according to Charaka. According to research, daytime sleep disturbs the daily activities of digestive enzymes. So, the derangement of sleeping patterns result in Agni Dushti and Dosha dushti. Shoka, Bhee, Atichinta, Krodha are the Manasika bhavas which causes Vata Kopa.

Stress and strain which are the result of present-day life is one of the risk factors of primary dysmenorrhoea. In classics these are the known causes of vitiation of Vata.
Due to hormonal changes adolescents tend to have more intense and wide-ranging emotions than children or adults. Increased pain sensation during the stressful condition is due to decrease in the level of testosterone, increase in cortisol level and activation of sympathetic nervous system. In conclusion, stress increases the activities of the hypothalamic- pituitary-adrenal axis and decreases hypothalamic-pituitary -gonadal axis activity and thereby increase in pain perception. Social withdrawal due to depressed mood could be yet another reason for the increased severity of the condition.

Pradushtartava: Artava, if taken as ovarian hormones in ovulatory cycle, they influence the release of prostaglandin and vasopressin. These hormones also modulate the sensitivity of uterus to these hormones and other factors which result in dysmenorrhoea. While considering primary dysmenorrhoea it can be taken as the hormonal imbalance especially in the levels of progesterone and prostaglandins. Prostaglandins are secreted under the influence of progesterone. So, variation in progesterone level causes increased prostaglandin synthesis and uterine contractions.

Beeja dosha: Congenital structural anomalies of genital tract and familial tendency of dysmenorrhoea can be taken under the heading Beeja Dosha. Functional abnormalities like cervical stenosis, uterine hypoplasia, uterine myometrial hyperactivity and hyperstimulation of nerve endings supplying uterine muscles can be considered due to Beeja Dushti.

Daiva means unknown or idiopathic causes: The exact cause of the disorder is not completely understood. However, there are many known factors that play a significant role in the pathogenesis of primary dysmenorrhoea. It is caused by myometrial activity resulting in uterine ischemia causing pain and this myometrial activity is modulated by prostaglandin synthesis. It is postulated that certain unknown factors may play a role in alteration in blood circulation and myometrial contraction.

\section{Role of Vata dosha in Udavarta yoni vyapat}

To understand the pathogenesis of this disorder understanding the role of Vata Dosha is inevitable. Menstrual bleeding is a function of Apana Vata. Apana Vata assists in all excretory activities such as passing of stool, 
and urine, ejaculation of semen, natural delivery of fetus. Artava (menstrual blood) gets excreted each month cyclically in women, comes under Apana Vata activity. Classics have mentioned location of Apana Vata as lower back, urinary bladder, genital tract and thighs. Obstruction to the outflow of blood by stenosis of internal os causes retention of menstrual blood and sets up irregular, spasmodic and painful menstruation. As per Ayurveda this obstruction is caused due to Vata. While considering the etiopathogenesis of primary dysmenorrhoea pain is related to dysrhythmic uterine contractions. Dysperistalsis and hyperactivity of the uterine junctional zone is another factor involved. Over activity of sympathetic nerve and hypertonicity of circular fibres of isthmus also contributing primary dysmenorrhoea. These factors also pointing to the involvement of Vata dosha.

\section{Role of Samprapti ghatakas in manifestation of dis- ease}

Vegadharana can be considered as the Vishesha $\mathrm{Ni}$ dana for Udavarta. Along with this intake of Vata Kopa Ahara Vihara leads to Vata Kopa especially Apana Vata. The derangement of Kapha occurs as Anubandha Dosha Dushti. Deranged Apana Vata causes Sanga and Vimargagamana in Artavavaha srotases and Sthana Samsraya in Yoni Garbhasaya. Due to vitiation of Apana Vata, Aakunjana and Prasarana does not takes place properly. This can be taken as the dysrythmia of uterine muscles which will hinder the proper flow of menstrual blood leading to Rajakrichrata. Besides this the main clinical feature of $U d a-$ varta is pain caused by the Viloma Gati of Vata and Artava. Here Vata vaigunya occurring either by Margavarodha i.e. anatomical or physiological obstruction or Doshavrita Margatwam which results in Sanga and Vimargagamana in the Artavavaha Srotas which in turn leads to painful menstruation or Udavarta.

Few hours prior to menstruation slight low backache and lower abdominal pain manifest as Purvarupa. $\mathrm{Vi}$ loma Gati of Vata and Rajas results in the manifestation of Rupa of Udavarta Yoni Vyapat such as severe Ruja during menstruation, Rajakrichrata, Phenila Artavam, Kapha Samsrishta Artava, Badha Rajas, Anya
Vata Vedana. Associated gastrointestinal and neurological symptoms may be due to deranged or decreased activity of Pitta and Vata Kopa. These Lakshanas starts along with the initiation of menstruation and sustains for 1-3 days depends on the type and degree of Dosha Dushti, with individual variations. A feeling of immediate relief following the proper flow of menstrual blood.

\section{CONCLUSION}

- Udavarta mainly affecting the females of adolescence period and late twenties, especially unmarried and nulliparous females.

- Udavarta has a positive familial background.

- Decreased Satwabala and anxious or stressed-out mental status are the factors contributing to worsen the agony caused by Udavarta.

- Vegadharana and Mithya Ahara Vihara causes Udavarta.

- Vitiated Apana Vayu is the causative factor for Udavarta, the Viloma Gati of Apana Vata associated with Artava causes pain.

- Vatanulomana, Shoola Hara, Vata Kaphahara, Sophahara, Srotovishodana are the properties of the drug doing Samprapti Vighatana and thereby curing Udavarta.

\section{REFERENCES}

1. Dutta DC. DC Dutta's Textbook of Gynaecology, 7th ed. Kolkata: New central Book agency: 2016. p.146

2. Vaidya Yadavji Trikamji Acharya, editor. Charaka Samhita Ayurveda Dipika commentary of Chakrapani Datta reprint ed. New Delhi: Chaukambha publications; 2014. chikitsa sthana Chapter 30, p.636.

3. Vaidya Yadavji Trikamji Acharya, editor. Charaka Samhita Ayurveda Dipika commentary of Chakrapani Datta reprint ed. New Delhi: Chaukambha publications; 2014. chikitsa sthana Chapter 30, p.636.

4. Srikanta Murthy KR. Trans. Vagbhata's Ashtanga Hridayam reprint ed. Varanasi: Chowkamba Krishnadas Academy; 2007 Vol III: Uttara Sthana Chapter 33, p.320

5. Vaidya Yadavji Trikamji Acharya, editor. Charaka samhita Chakrapani commentary reprint ed. Varanasi: Chaukambha publications; 2001 Chikitsa Sthana Chapter 30, p. 738,635 
6. Srikanta Murthy KR, translator. Vagbhata's Ashtanga Hridayam reprint ed. Varanasi: Chowkamba Krishnadas Academy; 2007, Vol III: Uttara Sthana Chapter 33, p.311

7. Sharma RK, Bhagwan Dash. Charaka Samhita text with English translation and critical exposition. Reprint Ed. Varanasi: Chaukambha Sanskrit series office; 2008. Vol. V: Chikitsa Sthana Chapter30, P.135

8. Srikanta Murthy KR, translator. Madava Nidana of Madhavakara reprint ed. Varanasi: Chaukhambha orientalia; 2013. Chapter 62, p.223

9. Srikanta Murthy KR, translator. Bhavaprakasha of Bhavamisra reprint ed. Varanasi: Chaukhambha Krishnadas Academy; 2016. Vol II: Chapter 70, p.779

10. Asha Kumari, Tewari PV, editors. Yogaratnakaram, 1st ed. Varanasi: Chaukhamba viswabharati; 2010. Part II: chapter 70, p.1136

11. Shivaprasad Sharma, editor. Sasilekha Sanskrit commentary by Indu, Varanasi: Chaukhambha Sanskrit series office sareerasthana chapter 38 p. 829

12. Yadunandana Upadhyaya, editor. Madhava nidana Madukosha Sanskrit commentary reprint ed. Varanasi: Chaukhambha Prakasan; 2018. Vol II: Chapter 62, p.418.

13. Sharma RK, Bhagwan Dash. Charaka Samhita text with English translation and critical exposition. Reprint Ed. Varanasi: Chaukambha Sanskrit series office; 2008. Vol. V: Chapter 30, p.157

14. Srikanta Murthy KR, translator. Ashtanga Samgraha of Vagbhata reprint ed. Varanasi: Chaukambha orientalia; 2012. Vol III: uttarasthana Chapter 39, p.341.

15. Srikanta Murthy KR, translator. Ashtanga Samgraha of Vagbhata reprint ed. Varanasi: Chaukambha Orientalia; 2012. Vol III: Uttarasthana Chapter 39, p.341.

16. Sadhana Dauneria, Jyoti Keswani. A study on the effect of yoga and naturopathy on dysmenorrhoea, Internati+onal journal of Yoga and Allied Sciences, Jan-June 2014; $3: 1$

\section{Source of Support: Nil \\ Conflict of Interest: None Declared}

How to cite this URL: Asitha. H \& N. Vijayakumar: Ayurvedic Perspective Of Primary Dysmenorrhoea - Review Article. International Ayurvedic Medical Journal \{online\} 2021 \{cited March, 2021\} Available from: http://www.iamj.in/posts/images/upload/2780_2786.pdf 